\title{
Analisis Fatigue Life Konstruksi Kapal Tanker 17500 DWT Menggunakan Metode Simplified Fatigue Analysis
}

\author{
Aryo Pangestu, Mohammad Nurul Misbah, dan Dony Setyawan \\ Departemen Teknik Perkapalan, Fakultas Teknologi Kelautan, \\ Institut Teknologi Sepuluh Nopember (ITS) \\ e-mail:mnmisbah@na.its.ac.id,dony@na.its.ac.id
}

\begin{abstract}
Abstrak-Kebutuhan minyak dunia diprediksi akan mengalami peningkatan pada tahun 2023 menjadi 100.4 juta barel. Peningkatan kebutuhan minyak dunia ini diikuti dengan peningkatan kegiatan eksplorasi dan eksploitasi minyak. Maka dibutuhkan fasilitas penunjang proses eksplorasi dan eksploitasi minyak, seperti kapal oil tanker. Diharapkan kapal oil tanker sebagai fasilitas penunjang mampu beroperasi dalam jangka waktu yang optimal. Selama kondisi operasional, kapal mengalami beban kerja berulang yang disebabkan oleh kondisi lingkungan pelayarannya yang dapat membahayakan struktur konstruksi kapal. Oleh karena itu, dibutuhkan perhitungan fatigue terhadap konstruksi kapal yang salah satunya dengan menggunakan metode simplified fatigue analysis. Analisis fatigue dilakukan pada sambungan pembujur sisi, pembujur alas dalam, dan pembujur alas terhadap sekat melintang akibat pengaruh dari tekanan dinamis gelombang dan tekanan sloshing muatan searah melintang kapal yang dihitung menggunakan rumus pada Common Structural Rules for Double Hull Oil Tanker (CSR). Analisis menggunakan variasi kondisi operasional muatan, yaitu $0.5 h_{\text {filling }}, 0.7 h_{\text {filling, }}$ dan $0.85 h_{\text {filling }}$ di mana untuk tiap masing-masing besar pembebanan diaplikasikan pada model tiga ruang muat. Proses analisis dibantu menggunakan software elemen hingga untuk mendapatkan hasil analisis dari variasi pembebanan. Berdasarkan hasil analisis, tegangan terbesar untuk sambungan pembujur sisi terjadi ketika kondisi muatan $0.85 h_{\text {filling, yaitu }}$ sebesar 56.3 MPa. Sambungan pembujur alas dalam pada

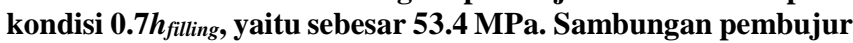

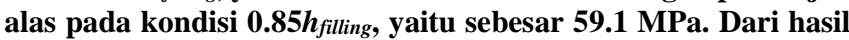
tegangan tersebut, didapatkan fatigue life untuk tiap sambungan adalah 26.6 tahun untuk sambungan pembujur sisi, 42.5 tahun untuk sambungan pembujur alas dalam, dan 30.4 tahun untuk sambungan pembujur alas.
\end{abstract}

Kata Kunci-CSR, Fatigue life, Kapal tanker, Simplified fatigue Analysis.

\section{PENDAHULUAN}

K EBUTUHAN minyak dunia setiap tahun mengalami kenaikan. Berdasarkan data dari International Energy Agency (IEA), pada tahun 2023 kebutuhan minyak dunia meningkat menjadi 100.4 juta barel[1]. Karena peningkatan kebutuhan minyak dunia yang meningkat, maka proses eksplorasi dan eksploitasi juga ikut meningkat sehingga diperlukan fasilitas penunjang yang cukup, salah satunya adalah kapal oil tanker. Selama pelayaran, kapal harus mampu bertahan terhadap beban kerja berulang yang terjadi selama pelayaran karena kondisi lingkungan.

Beban berulang yang terjadi secara terus menerus dapat mengakibatkan kelelahan pada struktur kapal. Beberapa insiden kecelakaan kapal akibat kelelahan pada struktur antara lain, M.V. Derbyshire pada tahun 1980 dan M.T.
Prestige pada tahun 2002. Pada tahun 2006, International Association of Classification Societies (IACS) mengembangkan regulasi terbaru untuk konstruksi kapal tanker dan bulk carrier yang bernama Common Structural Rules(CSR).

Karena beban berulang yang terjadi secara terus menerus dan dapat membahayakan struktur kapal, maka diperlukan analisis fatigue terhadap struktur konstruksi kapal. Terdapat beberapa metode dalam analisis fatigue, dalam penelitian ini digunakan metode simplified fatigue analysis.

Pada penelitian ini, dilakukan analisis fatigue yang difokuskan pada sambungan antara pembujur sisi, pembujur alas dalam, dan pembujur alas terhadap sekat melntang akibat pengaruh tekanan dinamis gelombang dan tekanan sloshing muatan searah melintang kapal.

\section{TINJAUAN PUSTAKA}

\section{A. Fatigue}

Fatigue atau kelelahan adalah suatu proses penjumlahan siklus demi siklus kerusakan pada struktur yang terkena tegangan yang berfluktuasi, melalui beberapa tahap dimulai dari keadaan awal "crack free" sampai ke keadaan "failure" atau kegagalan. Parameter beban yang paling berpengaruh adalah komponen tegangan yang berfluktuasi atau biasa disebut sebagai rentang tegangan [2]. Ada dua tipe kelelahan, yaitu :

1. Low-cycle fatigue, terjadi untuk jumlah siklus rendah, kurang dari $5 \times 10^{3}$ siklus

2. High-cycle fatigue, terjadi untuk jumlah siklus tinggi

\section{B. Metode Simplified Fatigue Analysis}

Metode alternatif yang dikembangkan untuk prosedur perhitungan sederhana dari beban dan tegangan yang bersifat long-term dinamakan metode simplified fatigue analysis. Loading case yang berbeda menggabungkan berbagai efek dinamis lingkungan pada struktur lambung yang dipertimbangkan untuk perhitungan rentang tegangan yang ditujukan untuk menutupi kondisi terparah[2]. Beban yang termasuk adalah :

1. Hull girder loads (contohnya : wave bending moment, momen torsional, dan gaya geser)

2. Beban eksternal tekanan gelombang

3. Beban internal yang berubah-ubah

\section{Beban pada Kapal}

Pada penelitian ini, beban yang digunakan adalah tekanan dinamis gelombang dan tekanan sloshing muatan searah melintang kapal. Tekanan dinamis gelombang didapatkan 
dengan menggunakan persamaan berikut [3] :

$P_{1}=2 f_{\text {prob }} f_{n 1-p 1}\left[\left(P_{11}+\frac{135 B_{\text {local }}}{4(B+75)}-1.2\left(T_{L C}-z\right)\right) f_{1}+\frac{135 B_{\text {local }}}{4(B+75)} f_{2}\right]$

(1)

$$
P_{2}=26 f_{\text {prob }} f_{n 1-p 2}\left[\begin{array}{l}
\left(\frac{B_{\text {local }}}{8} \theta+f_{T} C_{b} \frac{0.25 B_{\text {local }}+0.8 C_{W V}}{14}\left(0.7+\frac{2 z}{T_{L C}}\right)\right) f_{1} \\
+\left(\frac{B_{\text {local }}}{8} \theta+f_{T} C_{b} \frac{0.25 B_{\text {local }}}{14}\left(0.7+\frac{2 z}{T_{L C}}\right)\right) f_{2}
\end{array}\right]
$$

Dari kedua persamaan ini, diambil hasil yang terbesar dari perbandingan antara $\mathrm{P}_{1}$ dan $\mathrm{P}_{2}$. Sedangkan tekanan sloshing searah melintang kapal didapatkan dengan menggunakan persamaan berikut[3] :

$$
P_{\text {slh }-\mathrm{t}}=7 \rho g f_{\text {slh }}\left(\frac{b_{\text {slh }}}{B}-0.3\right) G M^{0.75}
$$

\section{Gerakan Rolling Kapal}

Gerakan rolling adalah gerakan rotasi kapal terhadap sumbu memanjang kapal. Untuk menghitung sudut roll kapal, digunakan rumus pendekatan sebagai berikut[3] :

$$
\theta=\frac{50}{B+75}\left(1.25-0.025 U_{\text {roll }}\right) f_{b k}
$$

\section{E. Konsep Metode Elemen Hingga}

Prinsip dasar dari metode elemen hingga ini adalah memperlakukan suatu sistem sebagai gabungan elemen- elemen kecil yang disebut finite element. Antar elemen digabungkan melalui titik-titik yang disebut nodes atau nodal point [4].

\section{F. S-N Diagram}

S-N diagram didapatkan dari percobaan material yang diberi beban tegangan yang berfluktuasi sesuai dengan regular sinusoidal [5]. Analisis elelahan berdasarkan pendekatan tegangan nominal, sambungan las dibagi menjadi beberapa kategori yang memiliki basic data diagram S-N [3]. Adapun basic data diagram S-N untuk tiap tipe sambungan berdasarkan CSR dapat dilihat pada Tabel 1 dan Gambar 1 adalah bentuk diagram S-N untuk sambungan las.

\section{G. Rentang Tegangan}

Rentang tegangan atau stress range pada perhitungan berdasarkan CSR ini dihitung dengan menggunakan persamaan berikut [3] :

$$
\begin{aligned}
& S_{e}=2 \sigma_{2 A e} \\
& S_{i}=2 \sigma_{2 A i}
\end{aligned}
$$

(5) adalah besar rentang tegangan untuk hasil pengaruh dari tekanan dinamis gelombang, sedangkan (6) adalah besar rentang tegangan untuk hasil pengaruh dari tekanan transverse sloshing. Karena input pembebanan pada analisis adalah kombinasi dari kedua beban, maka besar rentang

\begin{tabular}{|c|c|c|c|c|c|c|c|c|}
\hline \multirow{2}{*}{ Class } & \multicolumn{3}{|c|}{$K_{1}$} & \multirow{2}{*}{$\mathbf{m}$} & \multicolumn{2}{|c|}{ Standard Deviation } & \multirow{2}{*}{$\mathbf{K}_{2}$} & \multirow{2}{*}{$\mathrm{S}_{\mathrm{q}} \mathbf{N} / \mathbf{m m}^{2}$} \\
\hline & & $\log 10$ & $\log _{e}$ & & $\log 10$ & $\log _{e}$ & & \\
\hline $\mathrm{B}$ & $2.343 \mathrm{E} 15$ & 15.3697 & 35.3900 & 4.0 & 0.1821 & 0.4194 & $1.01 \mathrm{E} 15$ & 100.2 \\
\hline $\mathrm{C}$ & $1.082 \mathrm{E} 14$ & 14.0342 & 32.3153 & 3.5 & 0.2041 & 0.4700 & 4.23E13 & 78.2 \\
\hline $\mathrm{D}$ & 3.988E12 & 12.6007 & 29.0144 & 3.0 & 0.2095 & 0.4824 & $1.52 \mathrm{E} 12$ & 53.4 \\
\hline $\mathrm{E}$ & $3.289 \mathrm{E} 12$ & 12.5169 & 28.8216 & 3.0 & 0.2509 & 0.5777 & $1.04 \mathrm{E} 12$ & 47.0 \\
\hline $\mathrm{F}$ & $1.726 \mathrm{E} 12$ & 12.2370 & 28.1770 & 3.0 & 0.2183 & 0.5027 & $0.63 \mathrm{E} 12$ & 39.8 \\
\hline F2 & $1.231 \mathrm{E} 12$ & 12.0900 & 27.8387 & 3.0 & 0.2279 & 0.5248 & $0.43 \mathrm{E} 12$ & 35.0 \\
\hline G & $0.566 \mathrm{E} 12$ & 11.7525 & 27.0614 & 3.0 & 0.1793 & 0.4129 & $0.25 \mathrm{E} 12$ & 29.2 \\
\hline W & $0.368 \mathrm{E} 12$ & 11.5662 & 26.6324 & 3.0 & 0.1846 & 0.4251 & $0.16 \mathrm{E} 12$ & 25.2 \\
\hline
\end{tabular}
tegangan yang terjadi adalah dua kali tegangan yang dihasilkan.

Tabel 1

Basic Data Diagram S-N

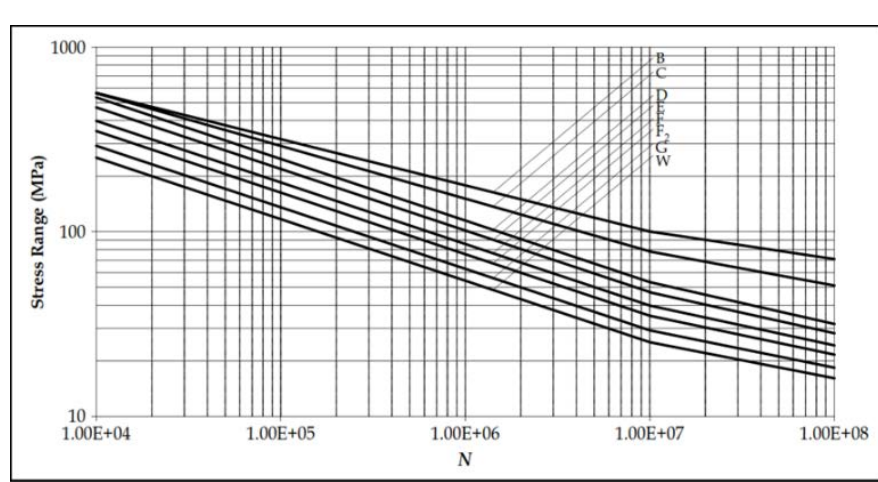

Gambar 1. Diagram S-N sambungan las menurut CSR.

\section{H. Perhitungan Fatigue}

Perhitungan kelelahan struktur oil tanker ini sesuai dengan penerapan aturan Palmgren-Miner cumulative damage. Ketika cumulative fatigue damage ratio, DM, memiliki nilai yang lebih besar dari 1, maka dapat dipastikan struktur tersebut mengalami kegagalan. Nilai DM dapat dihitung dengan menggunakan persamaan berikut[3] :
$D M_{i}=\frac{\alpha_{i} N_{L}}{K_{2}} \frac{S_{R i}^{m}}{\left(\ln N_{R}\right)^{m / \zeta}}$

Nilai DM dari persamaan di atas akan digunakan untuk menentukan umur kelelahan struktur sambungan dengan perhitungan umur kelelahan (fatigue life), yaitu:

FatigueLife $=\frac{\text { DesignLife }}{D M}$

Di mana design life menurut CSR adalah sebesar 25 tahun.

\section{METODOLOGI PENELITIAN}

\section{A. Pengumpulan Data}

Dalam proses penelitian ini, diperlukan data-data pendukung sebagai dasar dalam membuat model untuk analisis elemen hingga. Data kapal yang digunakan adalah data kapal tanker 17500 Double Hull LTDW dengan ukuran utama kapal tersebut dijelaskan pada Tabel 2. Selain itu, data lain yang dikumpulkan adalah berupa gambar rencana umum pada Gambar 2 digunakan untuk penentuan ruang muat yang akan dimodelkan dan gambar midship section pada Gambar 3 digunakan sebagai acuan detil konstruksi dari ruang muat yang akan dimodelkan. 
Tabel 2.

Data Ukuran Utama Kapal

\begin{tabular}{lcc}
\hline \hline \multicolumn{1}{c}{ Deskripsi } & Ukuran \\
\hline Displacement & $(\Delta)$ & $17500 \mathrm{ton}$ \\
Length Overall & $\left(\mathrm{L}_{\mathrm{OA}}\right)$ & $157.50 \mathrm{~m}$ \\
Length Between Perpendicular & $\left(\mathrm{L}_{\mathrm{PP}}\right)$ & $149.50 \mathrm{~m}$ \\
Breadth Moulded & $(\mathrm{B})$ & $27.70 \mathrm{~m}$ \\
Depth & $(\mathrm{D})$ & $12.00 \mathrm{~m}$ \\
Draught & $(\mathrm{T})$ & $7.00 \mathrm{~m}$ \\
Service Speed & $\left(\mathrm{V}_{\mathrm{S}}\right)$ & $13.00 \mathrm{knots}$ \\
\hline \hline
\end{tabular}

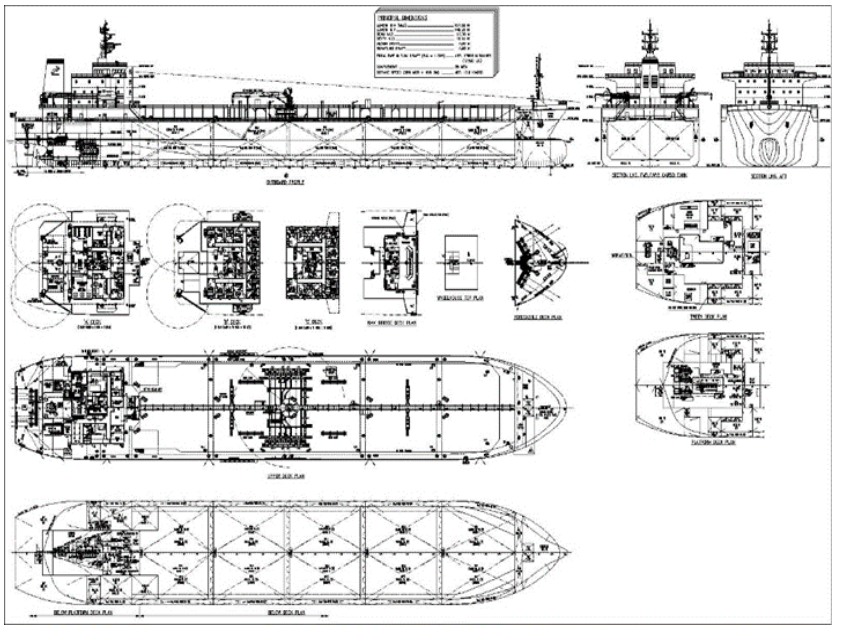

Gambar 2. Rencana umum kapal tanker 17500 LTDW

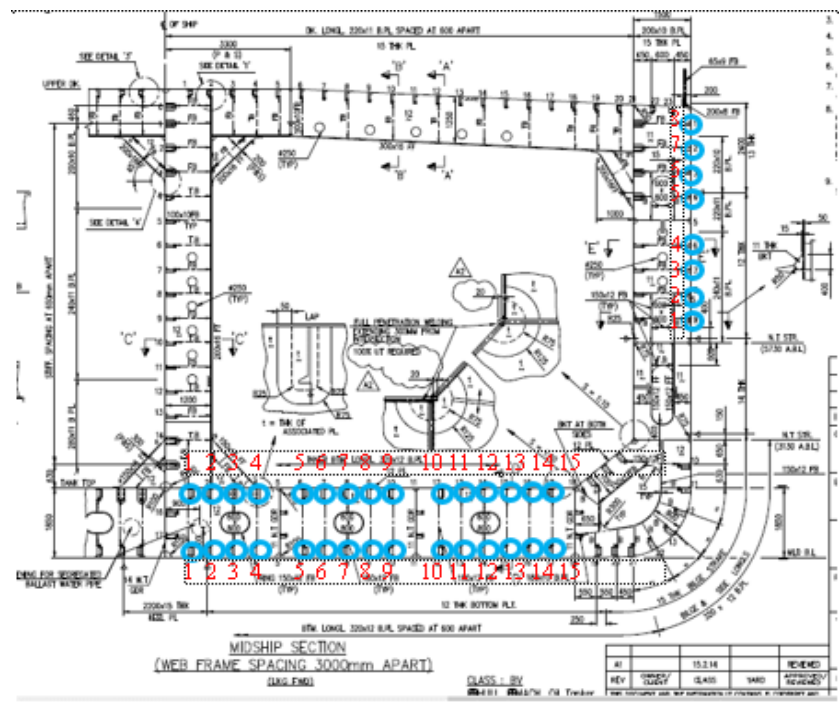

Gambar 3. Midship section kapal tanker 17500 LTDW beserta titik tinjau analisis
Selain data berupa gambar, data yang dikumpulkan juga termasuk intact stability booklet dari kapal tanker ini.

\section{B. Pembebanan}

Beban yang akan digunakan pada analisis ini dihitung berdasarkan (1) dan (2) untuk tekanan dinamis gelombang dan (3) untuk tekanan sloshing arah melintang kapal. Besar tekanan dinamis gelombang dan tekanan sloshing arah melintang kapal ini dipengaruhi oleh ketinggian muatan. Oleh karena itu, variasi yang digunakan adalah ketinggian muatan, yaitu $0.5 h_{\text {filling, }} 0.7 h_{\text {filling, dan } 0.85 h_{\text {filling }} \text { (muatan }}$ penuh). Untuk tiap kondisi pemuatan, ketinggian sarat kapal menjadi berbeda sehingga besarnya tekanan dinamis gelombang untuk tiap kondisi pemuatan berbeda. Besarnya sarat untuk kondisi $0.5 h_{\text {filling }}$ dan $0.7 h_{\text {filling }}$ didapatkan melalui interpolasi linear dengan batasan antara sarat kapal kosong dan sarat kondisi muatan penuh. Berdasarkan data intact stability booklet, sarat kapal kosong adalah sebesar $2.139 \mathrm{~m}$ dan sarat muatan penuh adalah $7 \mathrm{~m}$. maka dilakukan interpolasi linear sehingga didapatkan tinggi sarat untuk kondisi $0.5 h_{\text {filling }}$ dan $0.7 h_{\text {filiing }}$ secara berurutan adalah sebesar $4.99 \mathrm{~m}$ dan $6.142 \mathrm{~m}$. Tabel 3 menunjukkan hasil rekapitulasi tekanan dinamis gelombang, sedangkan Tabel 4 menunjukkan rekapitulasi tekanan transverse sloshing.

\section{Pemodelan}

Dalam analisis fatigue pada penelitian ini dibantu dengan penggunaan software elemen hingga. Untuk itu, diperlukan model konstruksi. Model konstruksi yang dibuat adalah tiga ruang muat di bagian midship kapal. Model konstruksi ini memiliki panjang $65.25 \mathrm{~m}$. Elemen yang digunakan adalah elemen Shell 281 yang memiliki 8 nodes untuk pelat dan Beam 189 yang memiliki 3 nodes untuk pembujur. Elemen ini dipilih untuk mendapatkan hasil tegangan yang lebih detil.

Material properties yang dimasukkan adalah sesuai dengan material properties baja A36 yang memiliki besar modulus Young $200 \mathrm{GPa}$, massa jenis $7850 \mathrm{~kg} / \mathrm{m}^{3}$, dan poisson ratio 0.3 . Kapal tanker ini memiliki jarak gading yaitu sebesar $0.6 \mathrm{~m}, 0.65 \mathrm{~m}$, dan $0.75 \mathrm{~m}$. Berdasarkan CSR ukuran elemen maksimum adalah sebesar 0.8, maka ukuran elemen yang digunakan adalah sebesar 0.6, 0.65, dan 0.75 . Gambar 4 menunjukkan hasil meshing dari model tiga ruang muat.

Tabel 3.

Rekapitulasi Tekanan Dinamis Gelombang

\begin{tabular}{|c|c|c|c|c|c|}
\hline $\mathrm{z}$ (m) 0.5hfilling & $P_{\text {ex-amp}}\left(k N / m^{2}\right)$ 0.5hfilling & z(m) 0.7hfilling & $P_{\text {ex-amp}}\left(k N / m^{2}\right)$ 0.7hfilling & $\mathrm{z}(\mathrm{m})$ 0.85hfilling & $P_{\text {ex-amp }}\left(k N / m^{2}\right)$ 0.85hfilling \\
\hline 0 & 73.725 & 0 & 78.733 & 0 & 82.462 \\
\hline 1.18 & 65.008 & 1.18 & 71.170 & 1.18 & 75.512 \\
\hline 2.49 & 55.331 & 2.49 & 62.773 & 2.49 & 67.796 \\
\hline 4.43 & 41.000 & 4.43 & 50.339 & 4.43 & 56.369 \\
\hline 4.99 & 36.863 & 6.055 & 39.924 & 6.055 & 46.789 \\
\hline 6.055 & 31.263 & 6.142 & 39.366 & 6.705 & 42.970 \\
\hline 6.705 & 27.844 & 6.705 & 35.583 & 7 & 41.231 \\
\hline 7.355 & 24.426 & 7.355 & 31.215 & 7.355 & 38.305 \\
\hline 8.005 & 21.008 & 8.005 & 26.847 & 8.005 & 32.945 \\
\hline 8.655 & 17.590 & 8.655 & 22.479 & 8.655 & 27.585 \\
\hline 9.305 & 14.172 & 9.305 & 18.111 & 9.305 & 22.225 \\
\hline 9.955 & 10.754 & 9.955 & 13.742 & 9.955 & 16.865 \\
\hline 10.605 & 7.336 & 10.605 & 9.374 & 10.605 & 11.505 \\
\hline 11.255 & 3.918 & 11.255 & 5.006 & 11.255 & 6.145 \\
\hline 11.79 & 1.104 & 11.79 & 1.411 & 11.79 & 1.734 \\
\hline 12 & 0.000 & 12 & 0.000 & 12 & 0.000 \\
\hline
\end{tabular}


Tabel 4.

Rekapitulasi Tekanan Transverse Sloshing

\begin{tabular}{cccccc}
\hline \hline & $\mathbf{h}_{\text {fill }}(\mathbf{m})$ & $\mathbf{f}_{\text {slh }}$ & $\mathbf{b}_{\text {tk-h }}(\mathbf{m})$ & $\mathbf{b}_{\text {slh }} \mathbf{( m )}$ & $\mathbf{P}_{\text {slh-t }}\left(\mathbf{k N} / \mathbf{m}^{2}\right)$ \\
\hline $0.05 \mathrm{~h}_{\max }$ & 0.534 & 0.155 & 11.584 & 11.584 & 4.792 \\
$0.1 \mathrm{~h}_{\max }$ & 1.068 & 0.28 & 12.091 & 12.091 & 9.997 \\
$0.15 \mathrm{~h}_{\max }$ & 1.601 & 0.395 & 12.397 & 12.397 & 15.244 \\
$0.2 \mathrm{~h}_{\max }$ & 2.135 & 0.5 & 12.397 & 12.397 & 19.296 \\
$0.25 \mathrm{~h}_{\max }$ & 2.669 & 0.595 & 12.397 & 12.397 & 22.962 \\
$0.3 \mathrm{~h}_{\max }$ & 3.203 & 0.68 & 12.397 & 12.397 & 26.243 \\
$0.35 \mathrm{~h}_{\max }$ & 3.737 & 0.755 & 12.397 & 12.397 & 29.137 \\
$0.4 \mathrm{~h}_{\max }$ & 4.270 & 0.82 & 12.397 & 12.397 & 31.645 \\
$0.45 \mathrm{~h}_{\max }$ & 4.804 & 0.875 & 12.397 & 12.397 & 33.768 \\
$0.5 \mathrm{~h}_{\max }$ & 5.338 & 0.92 & 12.397 & 12.397 & 35.505 \\
$0.55 \mathrm{~h}_{\max }$ & 5.872 & 0.955 & 12.397 & 12.397 & 36.855 \\
$0.6 \mathrm{~h}_{\max }$ & 6.406 & 0.98 & 12.397 & 12.397 & 37.820 \\
$0.65 \mathrm{~h}_{\max }$ & 6.939 & 0.995 & 12.397 & 12.397 & 38.399 \\
$0.7 \mathrm{~h}_{\max }$ & 7.473 & 1 & 12.397 & 12.397 & 38.592 \\
$0.75 \mathrm{~h}_{\max }$ & 8.007 & 0.995 & 12.397 & 12.397 & 38.399 \\
$0.8 \mathrm{~h}_{\max }$ & 8.541 & 0.98 & 12.397 & 12.397 & 37.820 \\
$0.85 \mathrm{~h}_{\max }$ & 9.075 & 0.955 & 12.397 & 12.397 & 36.855 \\
$0.9 \mathrm{~h}_{\max }$ & 9.608 & 0.92 & 12.397 & 12.397 & 35.505 \\
$0.95 \mathrm{~h}_{\max }$ & 10.142 & 0.875 & 12.397 & 12.397 & 33.768 \\
\hline \hline
\end{tabular}

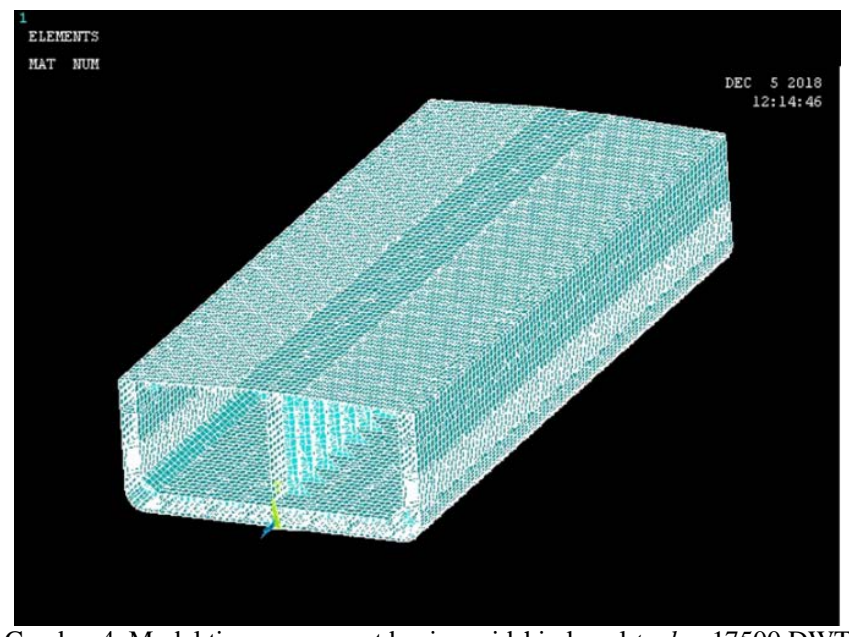

Gambar 4. Model tiga ruang muat bagian midship kapal tanker 17500 DWT

Kondisi batas yang ditetapkan oleh CSR diberikan pada independent point di kedua ujung model. Independent point adalah titik neutral axis dari model pada daerah tersebut. Untuk nodes di sekeliling didefinisikan sebagai rigid link [3].

Tabel 5.

Kondisi Batas

\begin{tabular}{lcccccc}
\multicolumn{1}{c}{ Kondisi Batas } \\
\cline { 2 - 7 } \multicolumn{1}{c}{ Lokasi } & \multicolumn{3}{c}{ Tranlasi } & \multicolumn{3}{c}{ Rotasi } \\
\cline { 2 - 7 } & $\delta_{x}$ & $\delta_{y}$ & $\delta_{z}$ & $\theta_{x}$ & $\theta_{y}$ & $\theta_{z}$ \\
\hline Ujung belakang (semua & Rigid & - & - & - & Rigid & Rigid \\
elemen memajang) & Link & & & & Link & Link \\
Independent point ujung & Fix & - & - & - & - & - \\
belakang & & & & & & \\
Ujung depan (semua & Rigid & - & - & - & Rigid & Rigid \\
elemen memanjang) & Link & & & & Link & Link \\
$\begin{array}{l}\text { Independent point ujung } \\
\text { depan }\end{array}$ & - & - & - & - & - & - \\
\hline \hline
\end{tabular}

\section{Perhitungan Fatigue Life}

Perhitungan cumulative fatigue damage harus dilakukan untuk mengetahui besar akumulasi kerusakan kelelahan akibat masing-masing kondisi pembebanan. Perhitungan cumulative fatigue damage sesuai dengan (7). Setelah nilai cumulative fatigue damage didapatkan, selanjutnya adalah menghitung fatigue life berdasarkan (8).

\section{HASIL DAN PEMBAHASAN}

\section{A. Analisis Tegangan}

Tegangan yang didapatkan melalui software elemen hingga nantinya akan dilakukan analisis untuk tiap kondisi pemuatan dengan variasi roll kanan dan roll kiri.

1) Kondisi $0.5 h_{\text {filling }}$

Sebelumnya dilakukan perhitungan sudut roll sesuai (4) dan didapatkan sudut roll sebesar $27.948^{\circ}$. Lalu dilakukan analisis dengan variasi gerakan roll kanan dan roll kiri dengan besar sudut roll yang sama. Gambar 5 dan Gambar 6 menunjukkan hasil solving kondisi $0.5 h_{\text {filling }}$.

2) Kondisi $0.7 h_{\text {filling }}$

Sebelumnya dilakukan perhitungan sudut roll sesuai (4) dan didapatkan sudut roll sebesar 27.333 . Gambar 7 dan Gambar 8 menunjukkan hasil solving kondisi $0.7 h_{\text {filling. }}$

\section{3) Kondisi $0.85 h_{\text {filling }}$}

Sebelumnya dilakukan perhitungan sudut roll sesuai (4) dan didapatkan sudut roll sebesar 26.339 . Gambar 9 dan Gambar 10 menunjukkan hasil solving kondisi $0.85 h_{\text {filling. }}$.

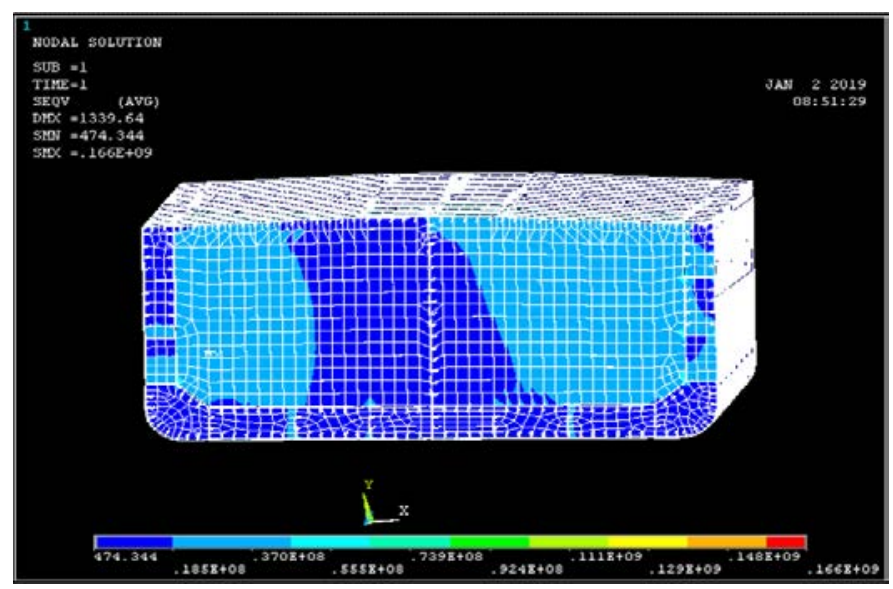

Gambar 5. Hasil solving pada kondisi $0.5 h_{\text {filling }}$ roll kanan 


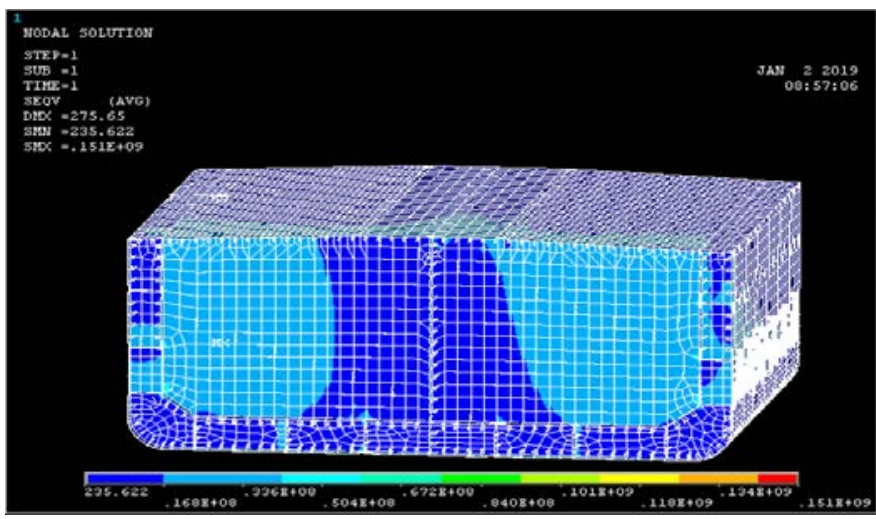

Gambar 6. Hasil solving pada kondisi $0.5 h_{\text {filling }}$ roll kiri

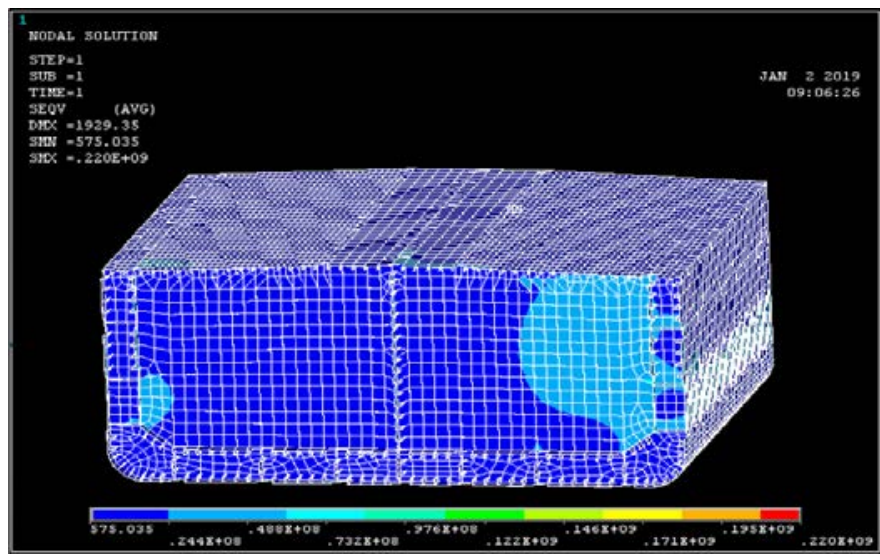

Gambar 7. Hasil solving pada kondisi $0.7 h_{\text {filling }}$ roll kanan

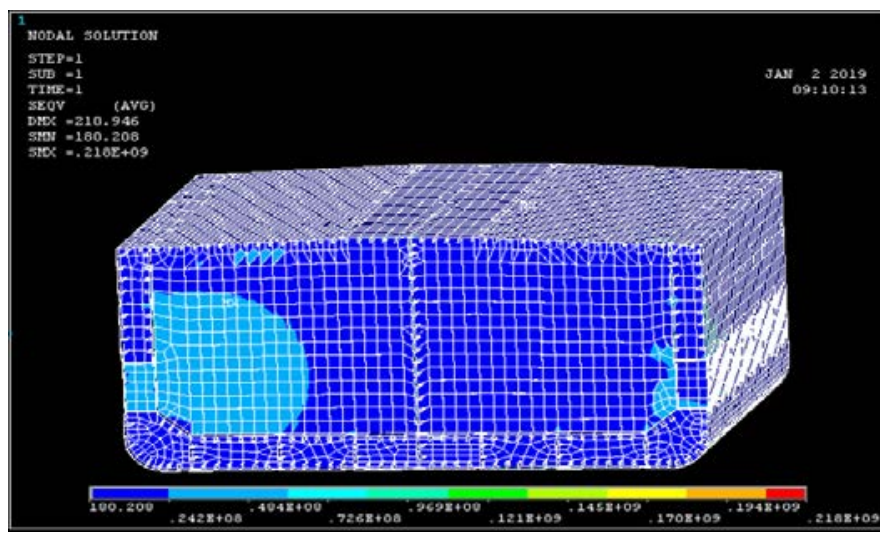

Gambar 8.Hasil solving pada kondisi $0.7 h_{\text {filling }}$ roll kiri

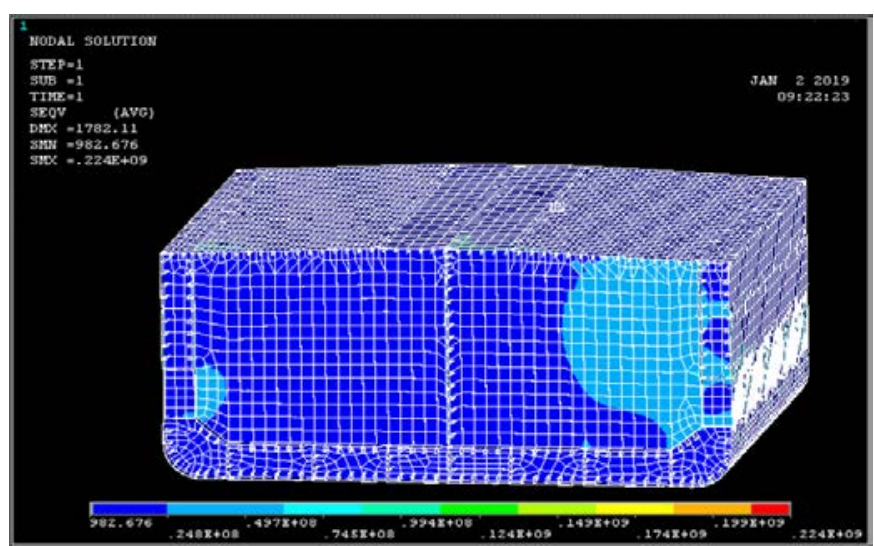

Gambar 9. Hasil solving pada kondisi $0.85 h_{\text {filling }}$ roll kanan

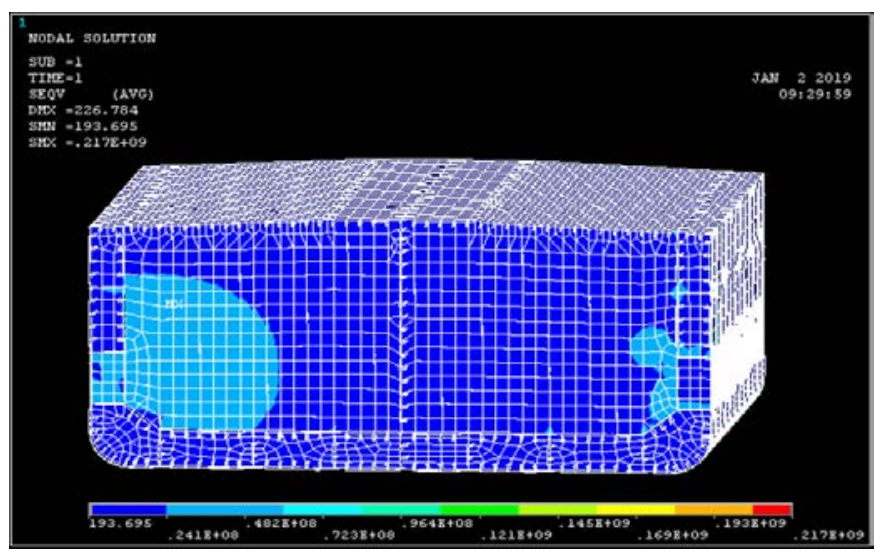

Gambar 10. Hasil solving pada kondisi $0.85 h_{\text {filling }}$ roll kiri

Tabel 6

Rekapitulasi Tegangan Maksimum $\left(\sigma_{\max }\right)\left(\mathrm{kN} / \mathrm{m}^{2}\right)$

\begin{tabular}{ccccccc}
\hline \hline Item & $\begin{array}{c}\text { Starboard } \\
\text { 0.5hfilling }\end{array}$ & $\begin{array}{c}\text { Port } \\
\text { 0.5hfilling }\end{array}$ & $\begin{array}{c}\text { Starboard } \\
\text { 0.7hfilling }\end{array}$ & $\begin{array}{c}\text { Port } \\
\text { 0.7hfilling }\end{array}$ & $\begin{array}{c}\text { Starboard } \\
\text { 0.85hfilling }\end{array}$ & $\begin{array}{c}\text { Port } \\
\text { 0.85hfilling }\end{array}$ \\
\hline Pembujur Sisi & 54.8 & 53.95 & 55.45 & 55.2 & 56.3 & 56.1 \\
Pembujur Alas Dalam & 46.1 & 45.7 & 53.4 & 53.2 & 48.9 & 48.6 \\
Pembujur Alas & 54.7 & 54.1 & 57.1 & 57 & 59.1 & 59 \\
\hline \hline
\end{tabular}

Dari hasil solving yang didapatkan, dapat dilihat sebaran tegangan antara kondisi roll kanan dan roll kiri tidak sama. Hal ini terjadi karena pengaruh dari web transverse dari sekat memanjang yang dipasang di sisi sebelah kanan pelat sekat memanjang. Tabel 6 menunjukkan hasil rekapitulasi tegangan maksimum untuk tiap sambungan pada tiap kondisi pemuatan.

\section{B. Perhitungan Cumulative Fatigue Damage}

Perhitungan nilai cumulative fatigue damage, DM, didapatkan dengan menggunakan (7). Perhitungan DM ini membutuhkan nilai rentang tegangan yang nilainya adalah dua kali tegangan yang dihasilkan menurut CSR. Pada penelitian ini, terdapat tiga kondisi operasional pembebanan, yaitu $0.5 h_{\text {filling }}, 0.7 h_{\text {filling }}$, dan $0.85 h_{\text {filling. }}$. Sehingga nilai persentase kondisi operasional pembebanan diasumsikan dengan nilai sebagai berikut:
$0.5 h_{\text {filling }}=20 \%$
$0.7 h_{\text {filling }}=30 \%$
$0.85 h_{\text {filling }}=50 \%$ 
Nilai akumulasi dari ketiga persentase kondisi operasional pembebanan harus sebesar $100 \%$. Tabel 7 menunjukkan hasil rekapitulasi nilai DM.

Tabel 7.

Rekapitulasi DM

\begin{tabular}{ccccc}
\hline \hline \multicolumn{5}{c}{$D M$} \\
\hline Item & 0.5 hfilling & 0.7 hfilling & 0.85 hfilling & $D M_{\text {total }}$ \\
\hline Pembujur Sisi & 0.860 & 0.918 & 0.986 & 0.940 \\
$\begin{array}{c}\text { Pembujur Alas } \\
\text { Dalam }\end{array}$ & 0.445 & 0.748 & 0.549 & 0.588 \\
Pembujur Alas & 0.688 & 0.792 & 0.894 & 0.822 \\
\hline \hline
\end{tabular}

\section{Perhitungan Fatigue Life}

Perhitungan fatigue life untuk tiap sambungan dilakukan ketika nilai DM didapatkan. Fatigue life dianggap memenuhi CSR ketika nilainya tidak kurang dari 25 tahun. Tabel 8 menunjukkan hasil rekapitulasi nilai fatigue life.

Tabel 8.

Rekapitulasi Fatigue Life

\begin{tabular}{ccc}
\hline \multicolumn{3}{c}{ Fatigue Life } \\
\hline Item & Fatigue Life (th) & Lokasi \\
\hline Pembujur Sisi & 26.6 & Pembujur 4 Starboard \\
Pembujur Alas & Side \\
Dalam & 42.5 & Pembujur 1 Starboard \\
Pembujur Alas & 30.4 & Side \\
& & Pembujur 1 Starboard \\
\hline \hline
\end{tabular}

\section{KESIMPULAN DAN SARAN}

\section{A. Kesimpulan}

1. Untuk sambungan pembujur sisi, tegangan terbesar terjadi pada kondisi $0.85 h_{\text {filling }}$ dengan besar $56.3 \mathrm{MPa}$.
2. Untuk sambungan pembujur alas dalam, tegangan terbesar terjadi pada kondisi $0.7 h_{\text {filling }}$ dengan besar 53.4 MPa.

3. Untuk sambungan pembujur alas, tegangan terbesar terjadi pada kondisi $0.85 h_{\text {filling }}$ dengan besar 59.1 MPa.

4. Nilai fatigue life terkecil untuk tiap sambungan adalah sebagai berikut :

a. Pembujur sisi sebesar 26.6 tahun.

b. Pembujur alas dalam sebesar 42.5 tahun.

c. Pembujur alas sebesar 30.4 tahun.

5. Umur kelelahan struktur konstruksi masih memenuhi persyaratan CSR sebesar 25 tahun.

B. Saran

1. Mengaplikasikan beban global, seperti wave bending moment baik horizontal maupun vertikal.

2. Memperhitungkan frekuensi sloshing muatan agar mendapatkan besar beban yang akurat untuk diaplikasikan pada model.

\section{DAFTAR PUSTAKA}

[1] I. E. A. (IEA), "Executive summary,” 2018.

[2] K. . Owen, F.H., \& Jeom, Ship structural analysis and design. New Jersey: Society of Naval Architects and Marine Engineers, 2010.

[3] I. A. of C. S. (IACS), "Common structural rules for double hull oil tanker,” 2014.

[4] D. Logan, "A first course in the finite element method," University of Wisconsin, 2007.

[5] W. Weibull, Fatigue testing and analysis of results. Oxford: Pergamon Press, 1961. 